\title{
THE RELATIONSHIP BETWEEN HUSBAND SUPPORT AND MIDWIFE ROLE WITH POST PARTUM CONTRACEPTION IN KONA WE KEPULAUAN DISTRICT
}

\author{
Dian Wulandari ${ }^{1}$, Sunarsih $^{2}$, Akbar Torontju $^{3}$ \\ ${ }^{1,2,3}$ Universitas Mandala Waluya, in Kendari Southeast Sulawesi Province, Indonesia
}

Corresponding Author : Dian Wulandari

Email : wulandaridian968@gmail.com

\section{Abstract}

Background: Postpartum contraceptive coverage in Konawe Kepulauan Regency in 2018, through data obtained at the Konawe Kepualaun District Health Office, Southeast Sulawesi Province as much as $8.4 \%$ and data in 2019 decreased to $1.26 \%$.

Methods:This quantitative research is observational with a cross sectional study design. The population in this study was 96 people with the determination of the sample using stratified cluster sampling, totaling 77 all post-partum mothers in the working area of the health centre in Konawe Kepulauan Regency.

Results:The significance value (p) value of husband support and the role of midwife is 0.000 which means that $\mathrm{p}<0.05$ so that $\mathrm{Ha}$ is accepted and Ho is rejected, which means that there is a significant correlation or relationship between husband's support and the role of midwives on the use of postpartum contraception. Both have a value of phi $\mathrm{C}$ which is 0.100 which meansvery weak relationship.

Conclusion: There is a relationship between husband's support and the role of the midwife against the use of postpartum contraceptives in the Konawe Islands district.

Key words: Support, Husband, Midwife, Contraception, Postpartum 


\section{INTRODUCTION}

Maternal mortality or maternal death according to the limits of The Tenth Revision of International Classification of Diseases (ICD-10) is a woman's death that occurs during pregnancy or within 42 days after pregnancy, regardless of the length and location of the pregnancy, caused by anything related to pregnancy. pregnancy, or was aggravated by the pregnancy, or its treatment, but not death caused by accident or chance(1).

The causes of direct maternal death in Indonesia are dominated by postpartum hemorrhage, hypertension, eclampsia, and infection. The need for community empowerment, then it requires cross-sector participation and involvement as well as parties who can provide role models in society(2). The indirect cause of maternal death is the number of cases 3 (three) too late and 4 (four) too. Case 3 (three) being late, includes: 1. Being late in recognizing the danger signs of childbirth and making a decision, 2. Being late in being referred to a health facility, and 3. Being late in being handled by a health worker at a health service facility Case 4 (four) too, covers: 1 Too old pregnant (over 35 years old), 2. Too young pregnant (under 20 years old), 3. Too many (more than 4 children), and 4 . Too close the distance between births (less than 2 years)(3).

In Indonesia, the coverage of postpartum contraception services is still far from the target set by the government, which is $80 \%$. Postpartum family planning service coverage in Indonesia in 2013 was $59.6 \%$. Postpartum family planning service achievement in urban areas was $60.9 \%$, while in rural areas it was $58.3 \%(4)$.

Postpartum family planning coverage for the Provision of Southeast Sulawesi in 2018 as many as 25628 people or as much as $4.69 \%(5)$.

The coverage of postpartum contraceptive use in Konawe Kepulauan Regency in 2018 shows as many as 73 people or $8.4 \%$ of the 869 births with 59 people using injection contraceptives (80.8\%), 10 people with Pill contraceptives (13.7\%), Family planning program of Implants for 4 (four) people (5.5\%) and IUD users were not there at all. Meanwhile, the contraceptive coverage data in 2019 amounted to 11 people or $1.26 \%$, consisting of 7 people using pill contraception $(0.8 \%)$ and 4 (four) people using injection contraception $(0.4 \%)$ and using IUD contraception and The Male Operation Method (MOP) / the Female Operation Method (MOW) did not exist at all from the total number of mothers who gave birth to 869 people. From these data, the coverage shows that public interest in the use of postpartum contraception is very low(5).

Based on this study, it shows that there are several problems regarding the achievement of postpartum contraception, especially in Kabubaten Konawe Islands, by looking at the national targets that have been set. So the researchers are interested in doing research on "The Relationship between Husband's Support and the Role of Midwives on the Use of Postpartum Contraception in Konawe Islands District".

\section{METHOD}

This quantitative research is observational with a cross sectional study design(6). The population in this study was 96 people with the determination of the sample using stratified cluster sampling, amounting to 77 all post-partum mothers in the working area of the Konawe Islands District Health Center. The study was conducted from December 14 to January 29, 2021.

\section{RESULTS}

Table 1 shows that of the 77 respondents based on the support of their husbands, 0 people are good $(0 \%)$, enough as many as 8 people $(10.38 \%)$, and less than 69 people $(89.61 \%)$.

Table 2 shows that of the 77 respondents based on the role of a midwife, 0 
people are good $(0 \%)$, enough as many as 8 people $(10.38 \%)$, and less than 69 people $(89.61 \%)$.

Table 3 shows that of the 77 respondents who answered that their husband's support was lacking by using postpartum contraception, not one respondent $(0 \%)$, while not using postpartum contraception there were 69 respondents $(100 \%)$. Of the 77 respondents who answered that their husband's support was sufficient by using postpartum contraception, there were 8 respondents $(100 \%)$ while none of those who did not use postpartum contraception (0\%), and of the 77 respondents who answered that their husband's support was good by using postpartum contraception there was none none of the respondents $(0 \%)$ so that at the time of testing the variables were illegible. This means that respondents with the support of their husbands do not use postpartum contraception more or less. The significance value $(\mathrm{p})$ value is 0.000 which means that $\mathrm{p}$ $<0,05$ so that $\mathrm{Ha}$ is accepted and Ho is rejected, which means that there is a significant correlation or relationship between maternal knowledge and postpartum

contraceptive use. And the value of phi $\mathrm{C}$ is 0.100 which meansvery weak relationship.

Table 4 shows that of the 77 respondents who answered that the role of midwives was less by using postpartum contraception, not one respondent $(0 \%)$, while there were 69 respondents $(100 \%)$ who did not use postpartum contraception. Of the 77 respondents who answered that the role of midwives was enough to use postpartum contraception, there were 8 respondents $(100 \%)$, while none of those who did not use postpartum contraception ( $0 \%)$, and of the 77 respondents who answered that the role of midwives was good by using postpartum contraception there were none none of the respondents $(0 \%)$ so that at the time of testing the variables were illegible. This means that respondents with the role of a midwife do not use postpartum contraception more or less. The significance value (p) value is 0.000 which means that $p<0,05$ so that $\mathrm{Ha}$ is accepted and Ho is rejected, which means that there is a significant correlation or relationship between maternal knowledge and postpartum contraceptive use. And the value of phi $\mathrm{C}$ is 0.100 which meansvery weak relationship.

Table 1

Husband's support according to respondents in Konawe Kepulauan district

\begin{tabular}{c|c|c|c}
\hline No. & Husband's support & $\mathrm{n}$ & $\%$ \\
\hline 1 & Good & 0 & 0 \\
\hline 2 & Enough & 8 & 10.38961039 \\
\hline 3 & Less & 69 & 89.61038961 \\
\hline \multicolumn{2}{r|}{ total } & 77 & 100 \\
\hline
\end{tabular}

Table 2

The role of the midwife according to respondents in Konawe Kepulauan district

\begin{tabular}{c|c|c|c}
\hline No. & The role of the midwife & $\mathrm{n}$ & $\%$ \\
\hline 1 & Good & 0 & 0 \\
\hline 2 & Enough & 8 & 10.38961039 \\
\hline 3 & Less & 69 & 89.61038961 \\
\hline \multicolumn{2}{|c|}{ total } & 77 & 100 \\
\hline
\end{tabular}

Indonesian Journal Of Health Sciences Research and Development 
Wulandari, D., Sunarsih, \& Torontju, A.

DOI: 10.36566/ijhsrd/Vol3.Iss1/74

https://ijhsrd.com/index.php/ijhsrd

e- ISSN: $2715-4718$

Table 3

Distribution of Husband's Support for Postpartum Contraception in Konawe

Kepulauan Regency

\begin{tabular}{c|c|c|c|c|c|c|c|c}
\hline \multirow{2}{*}{ No. } & \multirow{2}{*}{$\begin{array}{c}\text { Husband's } \\
\text { Support }\end{array}$} & \multicolumn{4}{|c|}{ Postpartum Contraception } & & \multirow{2}{*}{\begin{tabular}{c}
\multirow{2}{*}{ amount } \\
value
\end{tabular}} & \multirow{2}{*}{$\mathrm{C}$} \\
\cline { 3 - 6 } & & $\mathrm{n}$ & $\%$ & $\mathrm{n}$ & $\%$ & & & \\
\hline 1. & Enough & 8 & 100 & 0 & 0 & 8 & & \\
\hline 2. & Less & 0 & 0 & 69 & 100 & 69 & \multirow{2}{*}{0.000} & \multirow{2}{*}{0.100} \\
\hline & Total & 8 & 100 & 69 & 100 & 77 & & \\
\hline
\end{tabular}

Table 4

Distribution of the role of midwives on postpartum contraception in the district

Konawe Islands

\begin{tabular}{|c|c|c|c|c|c|c|c|c|}
\hline \multirow{3}{*}{ No. } & \multirow{3}{*}{$\begin{array}{l}\text { The role of } \\
\text { the midwife }\end{array}$} & \multicolumn{4}{|c|}{ Postpartum Contraception } & \multirow{3}{*}{ amount } & \multirow{3}{*}{$\begin{array}{c}\mathrm{p} \\
\text { value }\end{array}$} & \multirow{3}{*}{ C } \\
\hline & & \multicolumn{2}{|c|}{ Use } & \multicolumn{2}{|c|}{ do not use } & & & \\
\hline & & $\mathrm{n}$ & $\%$ & $\mathrm{n}$ & $\%$ & & & \\
\hline 1. & Enough & 8 & 100 & 0 & 0 & 8 & \multirow{3}{*}{0.000} & \multirow{3}{*}{0.100} \\
\hline \multirow[t]{2}{*}{2.} & Less & 0 & 0 & 69 & 100 & 69 & & \\
\hline & Total & 8 & 100 & 69 & 100 & 77 & & \\
\hline
\end{tabular}

is quite influential in determining the use of

\section{DISCUSSION}

\section{Relationship between Husband's Support and Postpartum Contraception}

This study shows that there is a relationship between husband's support and postpartum contraception in accordance with the results of hypothesis testing using chi square analysis. Based on the table, it is found that the significance value $(\mathrm{p})$ value is 0.000 , which means that $\mathrm{p}<0.05$ so that $\mathrm{Ha}$ is accepted and Ho is rejected, which means a significant relationship betweenhusband's support with postpartum contraceptionin Konawe Islands Regency.

According to the opinion of experts, Notoatmodjo S, in 2007 stated that family support is a set of interpersonal behavior, the nature, this activity is related to individuals in the family based on the behavior patterns of the family, group and society. In addition, family support is one of the reinforcing factors in the formation of behavior.The husband's opinion regarding family planning the family method by the wife. In previous research in Indonesia, the husband's consent was the most important factor in determining whether a wife would use contraception or not because the husband was seen as the protector, the breadwinner of the household, and the decision maker.(7).

Research that supports "Analysis of Achievement of Kb Post-Copy Intra Uterine Device (IUD)" shows that the support of husband and family is very influential on the use of postpartum contraceptives.(8). other than that"Factors Associated with Postpartum Birth Control in Postpartum Women in the Work Area of the Pakuan Baru Community Health Center in Jambi City in 2013" showed that there was a significant relationship between family support and postpartum family planning.(9).

\section{Relationship between the Role of Midwives and Postpartum Contraception \\ This study shows that there is a relationship between the role of midwives}


and postpartum contraception in accordance with the results of hypothesis testing using chi square analysis. Based on the table, it is found that the significance value $(\mathrm{p})$ value is 0.000 , which means that $\mathrm{p}<0.05$ so that $\mathrm{Ha}$ is accepted and Ho is rejected, which means a significant relationship betweenrole of midwives with postpartum contraception in Konawe Islands Regency.

Opinion of experts, according to(10), factors that influence interest in family planning such as reinforcing or reinforcing or encouraging (health workers).The implementation of the role of the midwife in the family planning program includes independent duties and government tasks, namely implementing health services which are a government program. In accordance with the authority of the midwife in implementing the family planning program, it is stated in Articles 9, 12, 13 and 15(11).

Supporting research"Factors Associated with Post-Copying Birth Control in Postpartum Women in the Work Area of the Pakuan Baru Community Health Center in Jambi City in 2013," it was found that there was a significant relationship between the role of health workers and postpartum family planning.(9). In addition, the supporting research entitled "Factors Associated with Willingness to Become Postpartum Family Planning Acceptor at Deli Serdang Lubuk Pakam Hospital in 2019", concludes that there is a significant relationship between the level of role of health workers related to willingness to be postpartum family planning acceptors.(12).

\section{CONCLUSION}

There is a relationship between husband's support and the role of the midwife against the use of postpartum contraceptives in the Konawe Islands district. So that the need for support from husbands and midwife coordinators in conducting mini workshop meetings conveyed a joint commitment to the use of postpartum family planning as well as conducting training for independent midwives in the working area of the Puskesmas in monthly meetings.

\section{REFERENCES}

1. World Health Organization. World health statistics 2015: World Health Organization; 2015.

2. Jayadipraja EA, Prasetya F, Azlimin A, Mando WOSY. Family clean and healthy living behavior and its determinant factors in the village of Labunia, Regency of Muna, Southeast Sulawesi Province of Indonesia. Public Health of Indonesia. 2018; 4 (1): 39-45.

3. Aryawati W. Development of a Planned and Anticipatory Model of Prevention of High Risk Pregnancy and Childbirth (REGITA). Indonesian Journal of Health Policy: JKKI. 2016; 5 (2): 86-93.

4. Anggraeni P. Determinants of LongTerm Contraceptive Method Use (MKJP) for Family Planning Acceptors in the Pamulang Community Health Center 2014: UIN Syarif Hidaayatullah Jakarta: Faculty of Medicine and Health Sciences, 2015; 2015.

5. Konawe Islands District Health Office. Coverage of postpartum contraceptive use in Southeast Sulawesi; 2019.

6. Mackey A, Gass SM. Second language research: Methodology and design: Routledge; 2015.

7. Fatimah D. Factors Related to the Use of Contraceptives in the Womb (IUD) in the Work Area of the Pasar Rebo District Health Center. 2013.

8. Wahyuni R, Irawan Y. Web-Based Heart Disease Diagnosis System With Forward Chaining Method (Case Study Of Ibnu Sina Islamic Hospital). Journal Of Applied Engineering And Technological Science (Jaets). 2019; 1 (1): 43-50. 
Wulandari, D., Sunarsih, \& Torontju, A.

DOI: 10.36566/ijhsrd/Vol3.Iss1/74

https://ijhsrd.com/index.php/ijhsrd

9. Ruwayda R. Factors Associated with Post-Copy $\mathrm{Kb}$ in Post-partum Mother in the Work Area of Puskesmas Pakuan Baru, Jambi City, 2013. Scientific Journal of Batanghari University, Jambi. 2017; 14 (1): 49-57.

10. Notoatmodjo S, Anwar H, Ella N, Tri K. Health promotion at school. Jakarta: inventions. 2012: 21-3.

11. RI D. Guidelines for the management of malaria cases in Indonesia. Jakarta: Ministry of Health of the Republic of Indonesia. 2008.

12. Sembiring JB, Suwardi S, Saragih HJ. Factors Associated with Willingness to Become Postpartum Family Planning Acceptor at Deli Serdang Lubuk Pakam Regional Hospital in 2019. Scientific Journal of Batanghari University, Jambi. 2020; 20 (2): 571-9. 